by Christopher J. Cleal ${ }^{1}$, Stanislav Opluštil ${ }^{2}$, Barry A. Thomas ${ }^{3}$ and Yanaki Tenchov ${ }^{4}$

\title{
Pennsylvanian vegetation and climate in tropical Variscan Euramerica
}

\author{
${ }^{1}$ National Museum Wales, Department of Biodiversity \& Systematic Biology, Cathays Park, Cardiff CF10 3NP, UK. \\ E-mail: chris.cleal@museumwales.ac.uk \\ ${ }^{2}$ Charles University in Prague, Faculty of Sciences, Albertov 6, 12843 Praha 2, Czech Republic. E-mail: oplustil@ natur.cuni.cz \\ ${ }^{3}$ Aberystwyth University, Institute of Biological, Ecological and Rural Sciences, Llanbadarn Fawr, Aberystwyth SY23 3AL, UK. \\ E-mail:bat@aber.ac.uk \\ ${ }^{4}$ Geological Institute, Bulgarian Academy of Sciences, G. Bonchev Street Block 24, 1113 Sofia, Bulgaria. E-mail: ytenchov@abv.bg
}

During late Westphalian and early Stephanian (late Moscovian) times there was a progressive westward withdrawal of the coal swamps from across Euramerica, eventually being restricted mainly to the basins of the Interior Province of North America. These changes can be correlated with the northwards migration of the Variscan Front that disrupted landscapes and drainage patterns. The resulting better-drained substrates caused localised change in the swamp vegetation from being lycopsid-to fern-dominated. Compared with the lycopsids, the ferns had non-determinate growth that produced less biomass per unit area, as well as producing vegetation with a more closed canopy, factors which combined to reduce overall evapo-transpiration. This in turn caused localised reductions in rainfall, which further affected the ability of the lycopsids to dominate the swamp vegetation. By Asturian times, most European coal swamps had mixed lycopsid - fern and fern dominated vegetation, eventually to be replaced by predominantly conifer and cordaite dryland vegetation. Lycopsid-dominated coal swamps persisted only in the westernmost parts of Euramerica, in the coalfields of the Interior Province of the USA, but even here they had disappeared by middle-late Cantabrian times. This tectonically-driven decline in the Euramerican coal swamps was probably responsible for an annual increase in atmospheric $\mathrm{CO}_{2}$ of c. $0.37 \mathrm{ppm}$, and may have been implicated in the marked increase in global temperatures near the Moscovian - Kasimovian boundary, and the onset of the Late Pennsylvanian nonglacial interval.

\section{Introduction}

It is widely accepted that the distribution of modern-day vegetation is strongly controlled by climate and that the same was largely true in the geological past. One of the most widely quoted Palaeozoic examples of this is the change that took place during Pennsylvanian (late Carboniferous) times in the wetlands of tropical Euramerica, popularly referred to as the coal swamps. At the end of Moscovian (Middle Pennsylvanian) times there is evidence of a marked increase in global temperatures, resulting in a contraction of the southern (Gondwana) polar ice-sheet (González, 1990; Fielding et al., 2008; Shi and Waterhouse, 2010) and a compositional change in the northern middle and high latitude Angaran vegetation (Meyen, 1982; Durante, 1995). Phillips and Peppers (1984) and Phillips et al. (1985) argued that this climate change also caused the dominant plants of the coal swamps to change from arborescent lycopsids to marattialean treeferns, and this view has become firmly established in the literature.

This model was mainly based on data from the westernmost parts of the Euramerican coal swamps, notably coalfields of the Interior and Appalachian provinces of the USA (sensu Nelson, 1987). In order to obtain a more complete picture of the changes that took place in the coal swamps in late Moscovian times, a five-year collaborative investigation as part of the International Geoscience Programme looked at the evidence from across Europe and the Canadian Maritimes - an area that we have called Variscan Euramerica (Cleal, 2004, 2008a; Jarzembowski, 2007). The complete report of IGCP 469 has been published in the Netherlands Journal of Geosciences (Cleal et al., 2010) but this article will briefly summarise the most important results.

For the rest of this account, the Heerlen chronostratigraphical scheme will be used as this was traditionally developed for the sequences of Variscan Euramerica and provides a better temporal resolution than the global IUGS Chronostratigraphy.

\section{Changes to the physical habitats}

Figure 1 summarises the lithostratigraphy in 11 coal basins between the Sydney Coalfield (Canadian Maritimes) in the west and the Dobrudzha Coalfield (Bulgaria) in the east. Using these data it has been possible to examine how the swamps changed in areal extent during late Westphalian times (Figure 2). At their maximum, in Bolsovian times, the coal swamps covered nearly $1,500 \times 10^{3} \mathrm{~km}^{2}$ of Variscan Euramerica, representing about a half of the total area of Euramerican coal swamps (Cleal and Thomas, 2005). Thereafter, the swamps in Variscan Euramerica, underwent a significant 


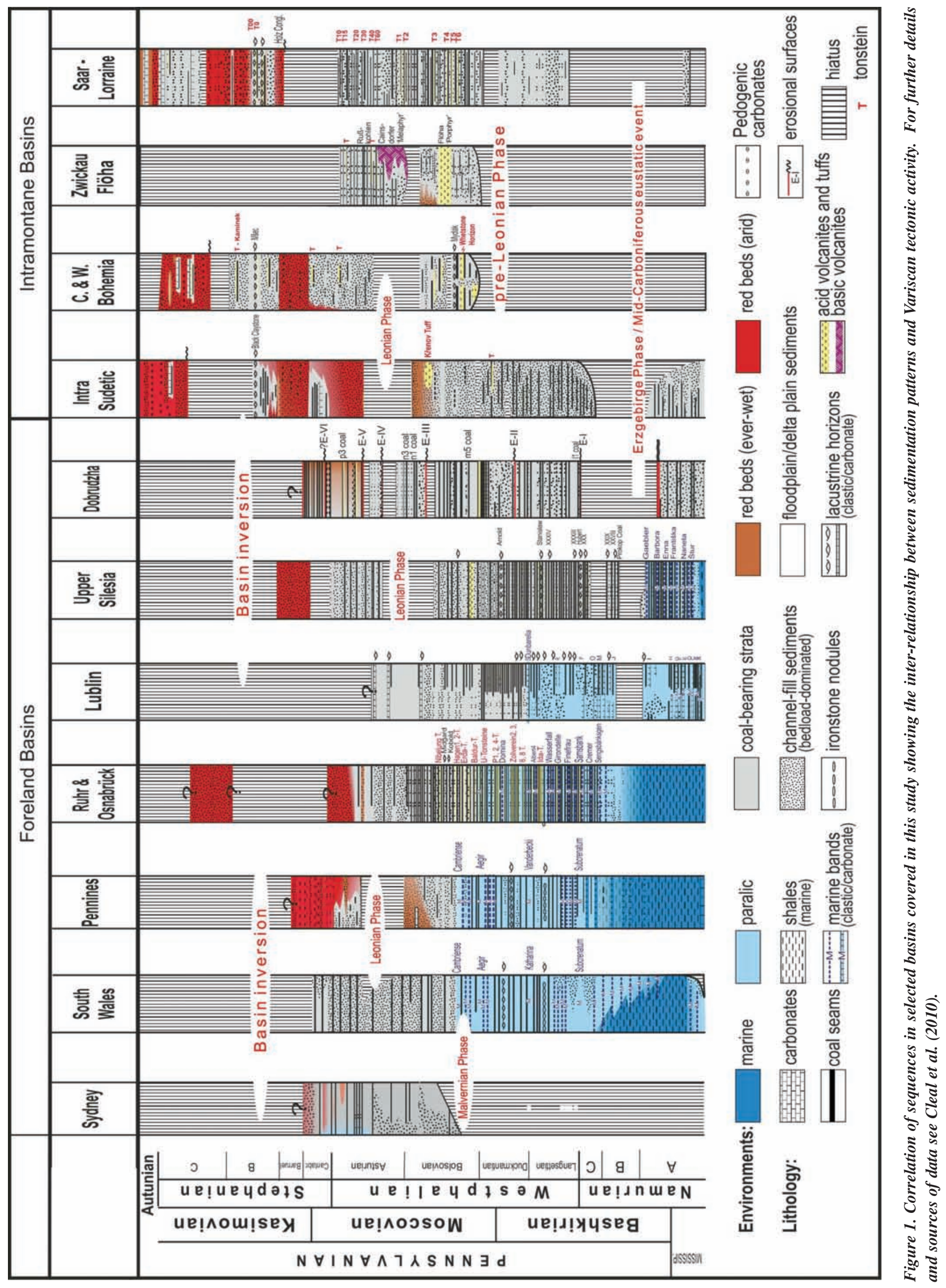


Late Duckmantian - early Bolsovian

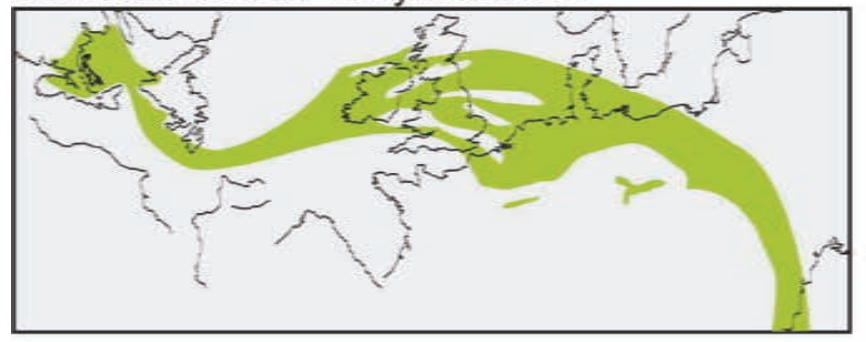

Early Asturian

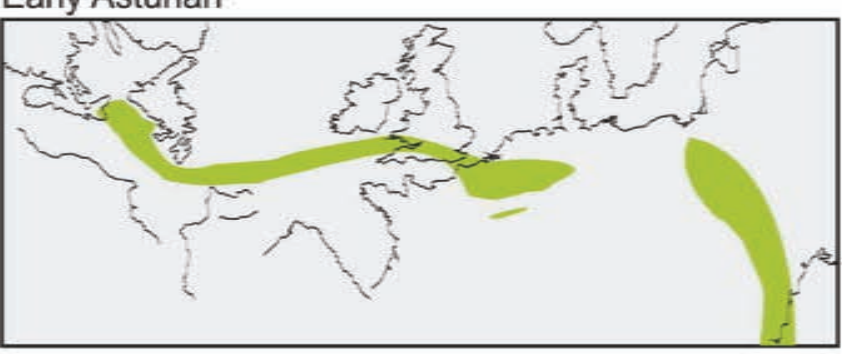

Late Asturian

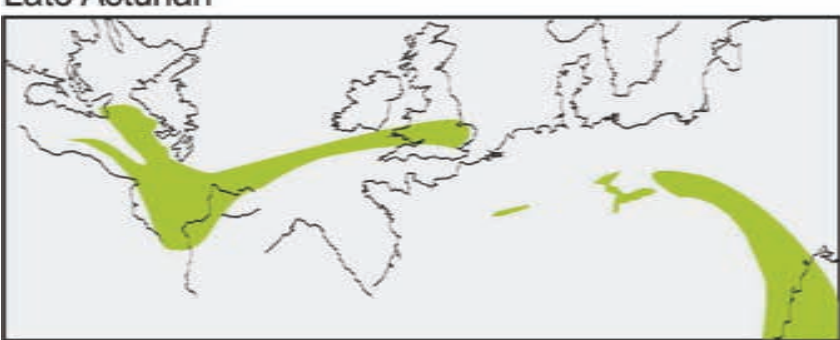

Late Bolsovian

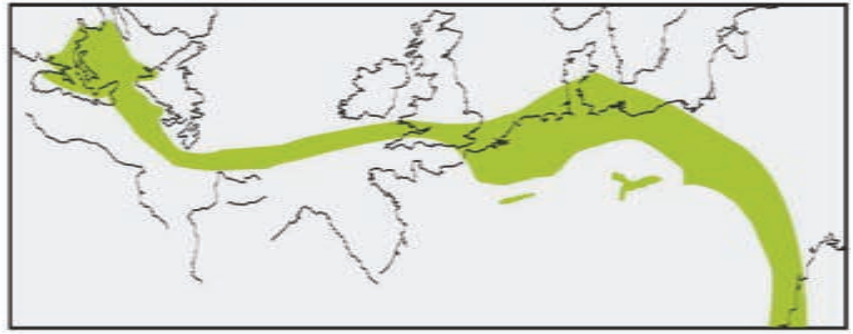

Middle Asturian

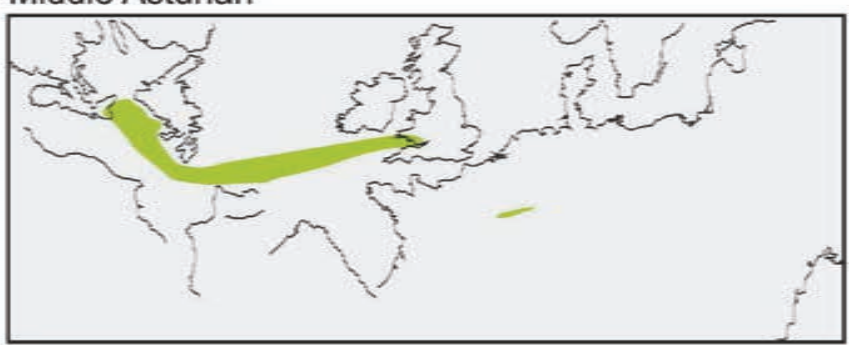

Early Cantabrian

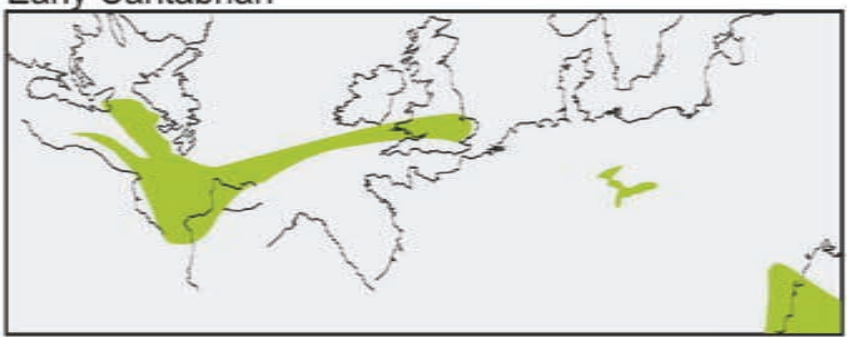

Figure 2. Distribution of coal swamps in Variscan Euramerica in six intervals from late Duckmantian to early Cantabrian times, essentially based around the sections summarised in Figure 1. The time bins are equivalent to the macrofloral zones/subzones: late Duckmantian early Bolsovian $=$ N. semireticulata Subzone, late Bolsovian $=$ L. rarinervis Subzone, early Asturian = L. obliqua Zone, middle Asturian = L. micromiltoni Subzone, late Asturian = D. plueckenetii Subzone, Cantabrian = O. cantabrica Zone.

contraction, ultimately disappearing by early-mid Cantabrian times, except for a few localised remnants in intra-montane basins (Figure 3).

During Namurian and Westphalian times there was also a gradual withdrawal of marine influence from Variscan Euramerica (Dreesen et al., 1995; Opluštil and Cleal, 2007). This increasing terrestrialisation of the foreland was at least partly a result of falling sea-levels in response to the growth of the Gondwana ice-sheet. The changes were strongly diachronous with marine influence appearing to withdraw westwards across the area: the youngest Carboniferous marine deposits in Upper Silesia are Alportian in age (Doktor and Gradzinski, 2000), in Lublin earliest Duckmantian (Shulga et al., 2007), in the Ruhr earliest Bolsovian and in Britain mid-Bolsovian. However, there is no obvious correlation with the diminishing area of the coal swamps. The Pennines basin, for instance, was among the last parts of the foreland to lose marine influence yet was one of the first to lose the coal swamps (Guion and Fielding, 1988; Guion et al., 1995). The two basins that retained the coal swamp habitats longest, South Wales and Dobrudzha, had completely different histories of marine influence: the former area retaining paralic conditions to mid Bolsovian times (Hartley, 1993), the latter never seeing any significant marine influence during Westphalian times (Tenchov, 2005, 2007).

The late orogenic or early post-orogenic intramontane basins represent fluvial valley-fills connected with the coastal lowlands via

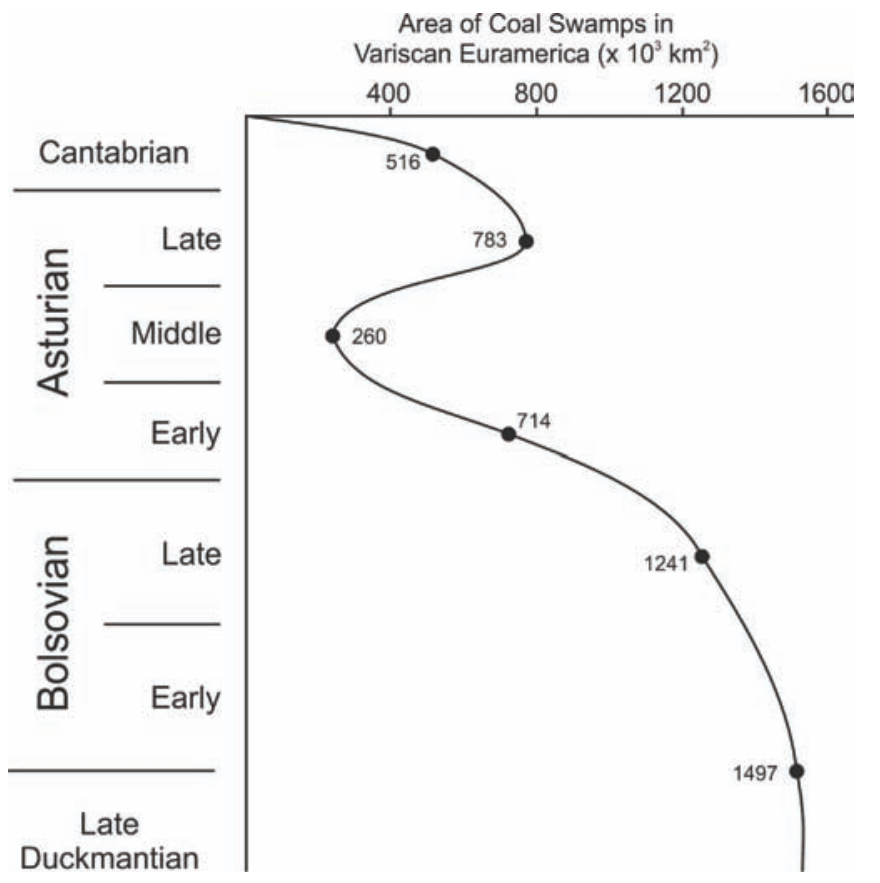

Figure 3. Changing area covered by coal swamps in Variscan Euramerica, based on maps shown in Figure 2. 
rivers which drained the Variscan Mountains (Opluštil, 2005; Gaitsch et al., 1998). There was considerable variation in the development of coal swamp habitats in these basins. In the Intra Sudetic Basin, for instance, deposition of coal-bearing strata had started already by late Mississippian times, whereas in Central Bohemia and Saar-Lorraine it did not start until late Duckmantian times (Pešek, 2004).

Against this background of withdrawing marine influence, there was also a progressive increase in tectonic activity affecting both the foreland and intra-montane basins. This is most evident in eastern and central Europe, with several non-sequences and influxes of coarse clastic sediment in the Dobrudzha, Upper Silesia, Central Bohemia, Zwickau and Intra-Sudetic successions (e.g. Tenchov, 1993; Pešek, 1994; Schneider et al., 2005; Kedzior et al., 2007). There are also non-sequences in the more western basins in the higher Westphalian parts of the successions and, especially in the midBolsovian Substage, where there was also an increase in the input of coarse clastic sediment, such as the Pennant Formation in the British Isles (e.g. Gayer and Jones, 1989; Besly and Cleal, 1997). There was also an increase in the development of red-beds in many of the successions, which in pre-Asturian times was mainly due to lowered water tables caused by changing drainage patterns within the basins (Besly and Turner, 1983; Besly and Fielding, 1989), which were also likely a response to landscape changes caused by tectonic activity.

The tectonic activity that caused these changes to sedimentation patterns was sometimes local in effect, but there were also several more widespread events. For instance, there is evidence of widespread activity in mid-Asturian times, which is often referred to as the Leonian Phase (Wagner, 1966). Especially in the more western areas, tectonic activity in mid-Bolsovian times associated with the northwards migration of the Variscan Front (Gayer et al., 1993) has been referred to as the Malvernian Phase (Moore and Blundell, 1952). And most widespread of all was the basin inversion in mid-Cantabrian times, which is widely referred to as the Asturian Phase (despite it being significant earlier than the classic Asturian tectonics of northern Spain - Wagner and Winkler-Prins, 1970). The so-called Asturian Phase caused sedimentation across Variscan Euramerica to either cease or in a few areas (e.g. Canadian Maritimes and Pennines basins) to change to coarse clastic deposition.

Climatic signals in the sedimentary record of these basins are provided by the distribution of red coal-barren and grey coal-bearing strata, the character of soils and coal seams (Besly, 1987; Opluštil and Cleal, 2007). Red-beds in which palaeosol evidence indicates more arid conditions appear in the Pennines, Ruhr, Dobrudzha and Intra Sudetic basins in the Asturian Substage (e.g. Besly, 1988) but these changes seem to be localised; elsewhere, such as the Canadian Maritimes, South Wales, Saar-Lorraine, Upper Silesia and Western and Central Bohemia basins red-beds are limited in extent or totally absent, and grey coal-bearing strata still dominate. Red-bed deposition did not become widespread across Variscan Euramerica until early Stephanian (Barruelian) times, but then continued through most of the Stephanian Epoch except for a temporary base-level rise causing extensive lacustrine and coal-bearing deposits in Stephanian B times, mainly in the intra-montane basins (e.g. Lojka et al., 2009).

\section{Palynology}

There has been extensive research into the palynology of the Euramerica coal deposits for over a century (e.g. see Marshall, 2005) but mainly as a guide to stratigraphical correlation. Smith (1957, 1962) and Butterworth (1964) showed that palynology also had the potential for revealing evidence of the composition and ecology of the swamp but this tended to be hampered by uncertainties as to the parent plants of many of the palynomorphs. However, with improved evidence now available from in situ pollen and spores (e.g. Balme, 1995; Bek and Opluštil, 1998) it has been possible to translate the palynological record into changes in the representation of the major plant groups, which gives at least some indication of the overall changes in the vegetation of the coal swamps.

In the Dobrudzha Basin in the eastern part of the Variscan Foreland, the palynology of the coals in the Bolsovian part of the succession revealed a mixed lycopsid - fern vegetation, with the arborescent lycopsids mainly found in pioneer vegetation of the swamps; the climax communities tended to be dominated by tree ferns (Dimitrova and Cleal, 2007). In the stratigraphically higher, Asturian - Cantabrian palynofloras, the swamp vegetation had become almost totally dominated by tree ferns. An essentially similar pattern has been found in the coals in Upper Silesia (Jachowicz, 1972; Jachowicz and Dybova-Jachowicz, 1983; Opluštil, 2004) and Bohemia (Opluštil et al., 1999; Pešek, 2004).

In more western parts of the foreland, Duckmantian and early Bolsovian wetland vegetation consisted almost exclusively of arborescent lycospids, with Lycospora dominating the palynofloras of both the coals and clastics (e.g. Marshall and Smith, 1964; Jasper et al., 2010). Evidence from younger coals in the more western parts of the foreland is limited, but palynofloras from the roof shales of the younger coals in southern Britain and the Canadian Maritimes suggest an essentially mixed lycopsid - fern vegetation was dominant (Dimitrova et al., 2005, 2010; Cleal et al., 2007).

This is all in marked contrast to the evidence from the Midcontinent, Illinois and Appalachians, which suggests that the arborescent lycopsids dominated the swamp vegetation until early Stephanian (late Desmoinesian) times and that the change to ferndominated vegetation was relatively abrupt (Peppers, 1996). In Variscan Euramerica the transition was gradual with an extensively developed intermediate phase of mixed lycopsid - fern vegetation. Moreover, the change was diachronous, occurring first in eastern Variscan Euramerica and then spreading westwards towards western Europe and the Canadian Maritimes (Figure 4).

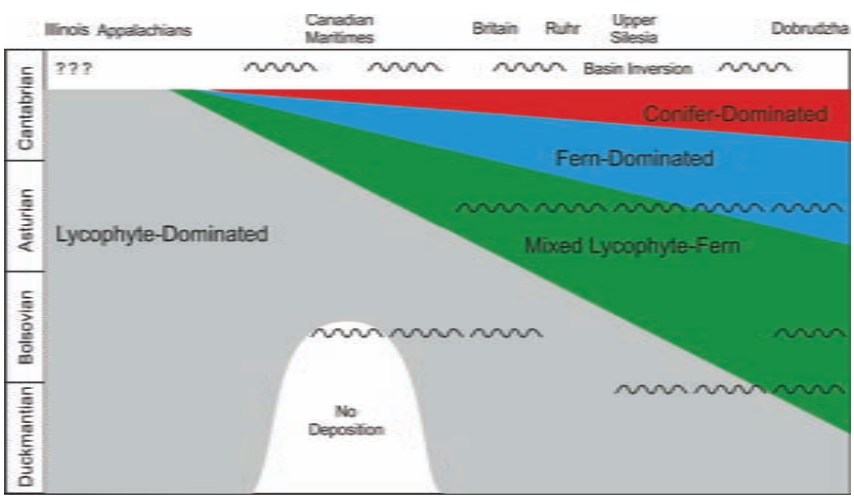

Figure 4. A diagrammatic representation of how the coal swamps progressively changed in composition during late Westphalian and early Stephanian times across the foreland areas of Euramerica, based mainly on palynological evidence. The undulating lines represent periods of tectonic instability. The horizontal scale represents the approximate distances between the basins. 


\section{Macrofloras}

The original American model relied heavily on coal ball petrifactions to provide direct evidence of vegetation changes, and such fossils undoubtedly provide an accurate picture of the plants growing on the peat substrates. However, such fossils are unknown from the upper Westphalian Stage of most of Europe (Galtier, 1997). Only the Donets Basin in Ukraine has yielded such fossils (Snigirevskya, 1972) but these have not been completely documented. There is also a problem with the use of coal balls for determining wider patterns of vegetation as they are mostly autochthonous or growing in the immediate vicinity; you need to examine coal ball floras over a considerable geographical area to get an understanding of the overall vegetation. This is in contrast to the adpressions and especially the palynology, which because they have usually been subject to transportation prior to fossilisation give a more averaged signal of the vegetation composition.

Macrofloral analysis of the vegetation of Variscan Euramerica was therefore based on the adpression record. Although the full range of plant groups preserved as adpressions was considered, particular emphasis was given to the arborescent lycopsids and the pteridosperms parautochthonous remains and therefore only show what plants were

(Medullosales, Lyginopteridales, Callistophytales), which for mainly taphonomic reasons occur as abundant adpressions and have a relatively stable taxonomy.

Overall species diversities in the macrofloras vary between basins (Figure 5). In South Wales, the Canadian Maritimes and SaarLorraine, diversities remain relatively static between the Duckmantian and lower Cantabrian substages, with just minor reductions in the upper Bolsovian Substage and a subsequent rise in the middle Asturian Substage (Cleal, 2007; Cleal et al., 2007; Uhl and Cleal, 2010). As these relatively subtle changes in diversities can be identified in both foreland and intra-montane basins, it is likely that they may have been responses to climate change. Overall, however, conditions in the swamp habitats appear to have been relatively stable in these areas. In the Pennines and Ruhr basins, in contrast, there is a marked fall in diversities in the Bolsovian Substage (Cleal, 2005, 2008b; Uhl and Cleal, 2010). These are accompanied by changes in patterns of sedimentary deposition (increased input of coarse clastic sediment and a fall in water tables) and the changing vegetation would thus seem to be responses to these intra-basinal habitat changes rather than climate.

Biostratigraphical (e.g. Cleal and Shute, 2003; Šimunek, 2004, 2007; Bek and Opluštil, 2004) and biogeographical (Thomas and Tenchov, 2004; Thomas, 2007; Cleal, 2008c, 2008d) studies on the
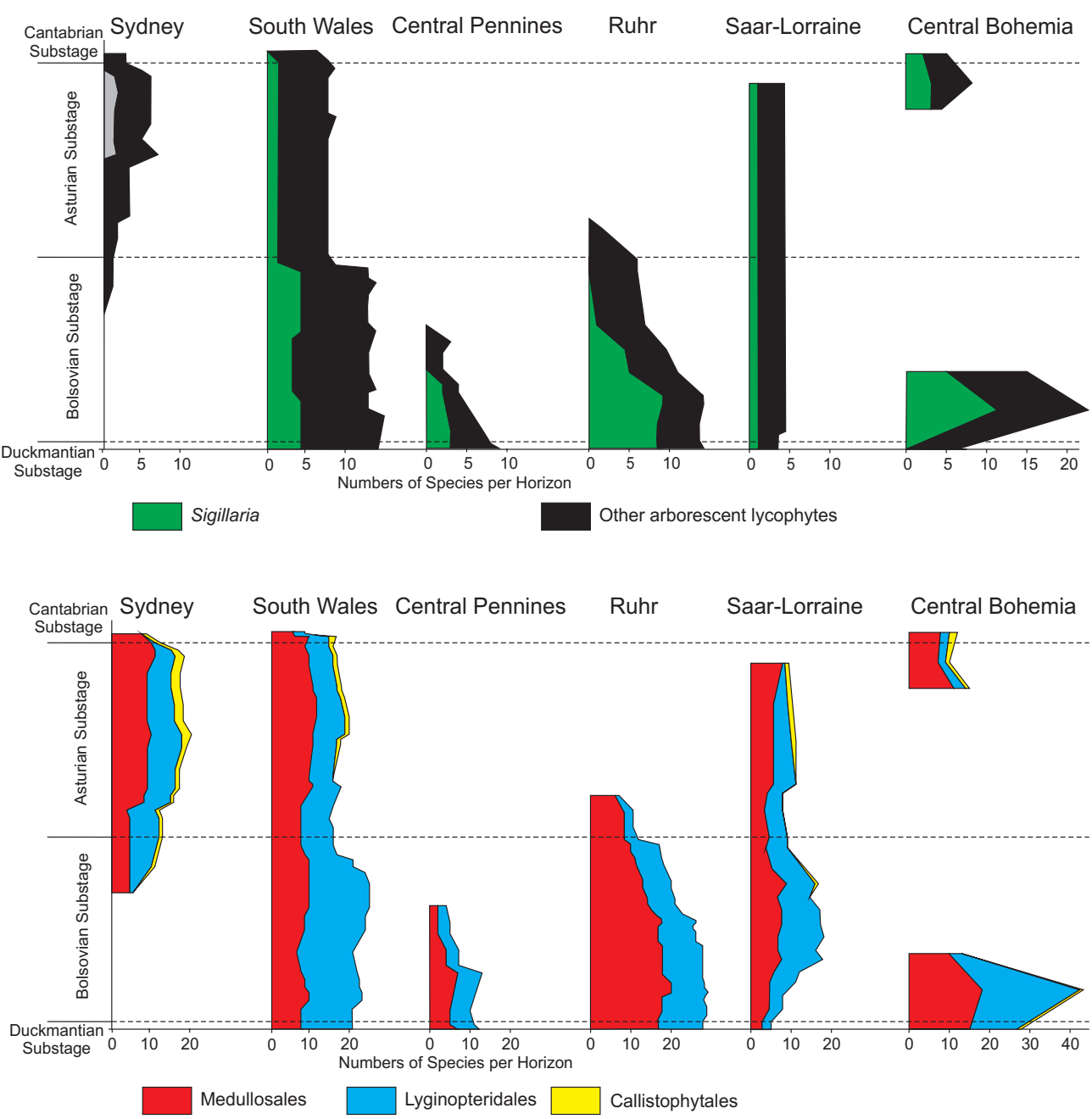

Figure 5. Changing species diversities among the lycopsids (upper) and pteridosperms (lower) in the Bolsovian to lower Cantabrian substages of six coalfields in Variscan Euramerica. See text for sources of data. macrofloras also suggest that where habitats remained suitable for the development of the coal swamp habitats, conditions remained relatively stable through late Westphalian and early Stephanian times.

One unexpected outcome from these studies was that two groups of plants - the medullosalean pteridosperms bearing Alethopteris fronds and the arborescent lycopsids with Sigillaria stems - were among the first to go into decline and disappear in those areas that suffered habitat changes in the middle Westphalian Stage. This was unexpected because both plant groups were thought to be better adapted to drier conditions, having been able to survive the Middle-Late Pennsylvanian changes to the coal swamps (e.g. DiMichele and Phillips, 1996). However, some of the characters of Alethopteris fronds that have been interpreted as xeromorphic adaptations, such as papillate and/or sunken stomata (Cridland, 1968) may in fact have been adaptations to extreme wet conditions that helped avoid the stomata being blocked by excessive surface water (see comments by Wilkinson, 1979, on such features in modern-day rainforest plants). The situation with Sigillaria is more problematic. Although there is some 
evidence that these lycopsids could grow on better drained substrates (DiMichele et al., 2005) our knowledge of their habitat tolerances is rather limited.

\section{Faunas}

Westphalian age terrestrial faunas of Variscan Euramerica are still relatively poorly known. Insect remains are the most extensively studied. Although such fossils are not abundant in many localities there have been attempts to develop biostratigraphical schemes (e.g. Jarzembowski and Schneider, 2007). During late Westphalian - early Stephanian times, for instance, it has been shown that archaic Archimylacris gave way to patterned Sysciophlebia and Syscioblatta (Figure 6) However, the ecological or palaeoclimatic significance of this remains uncertain. Arachnid remains have also been widely found but few taxa have been reported from more than one locality, making distributional studies difficult (although see comments by Dunlop, 1994, that this may in part reflect an over-splitting of the species taxonomy).

Decomposition of plant material resulted in very low $\mathrm{pH}$ levels in the coal-bearing deposits of Variscan Euramerica. Vertebrate remains therefore tend to be extremely rare but become a little more abundant in the red-beds (a similar relationship between red/grey beds and vertebrate preservation has been noted in Triassic deposits of Gondwana - Anderson et al., 1998).

Freshwater faunas were not considered as part of IGCP 469, partly

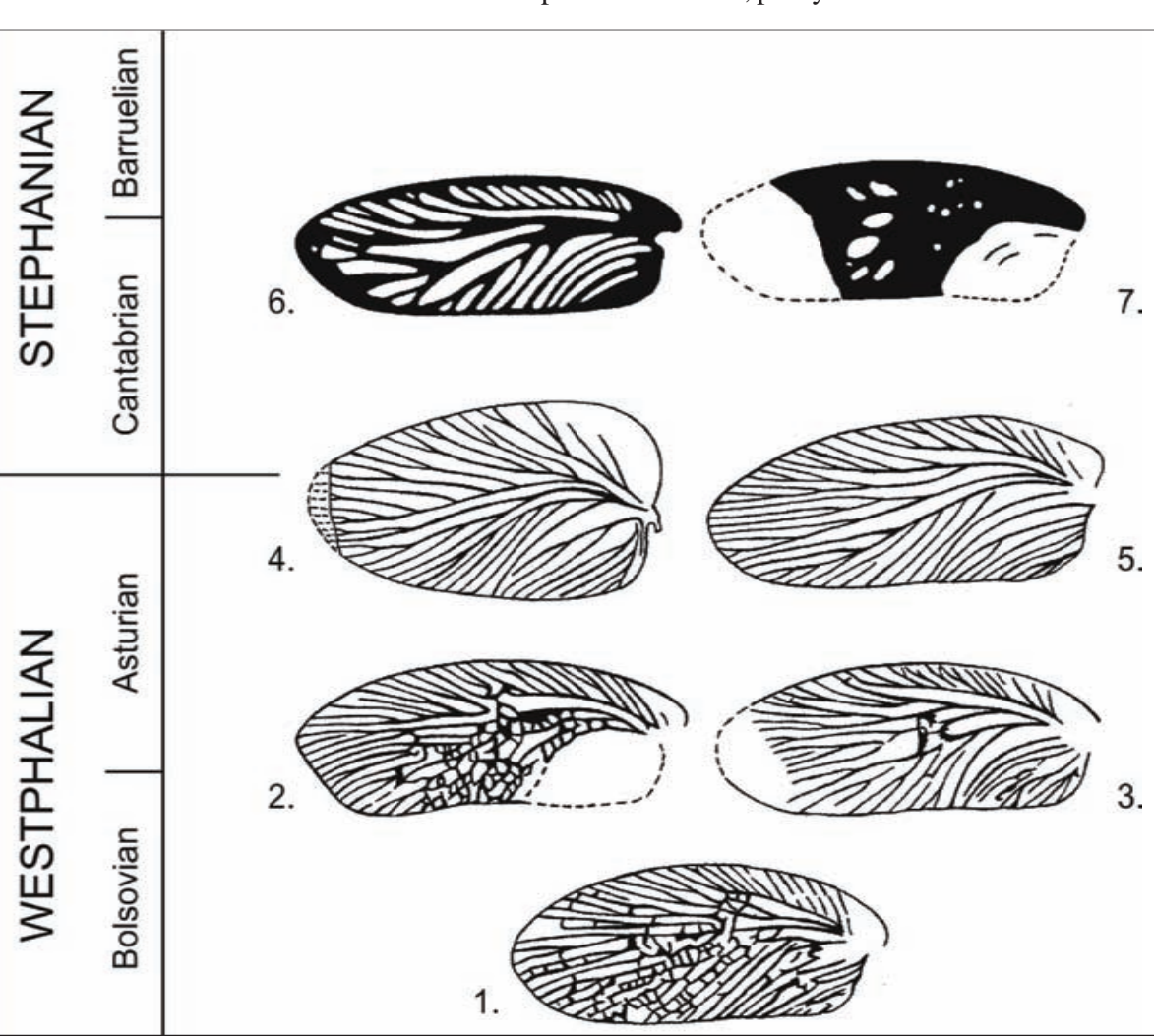

Figure 6. Zonal cockroachoids for the mid Westphalian-early Stephanian, based on Jarzembowski et al. (in Cleal et al., 2010). Key to species: 1, Archimylacris lubnensis Kušta; 2, Archimylacris $f$. Zwickau; 3, Kinklidoblatta morini (Provost); 4, Sooblatta burri (Bolton) (representing the Mylacris abrupta-Sooblatta burri-Sooblatta deanensis Assemblage Zone); 5, 'Syscioblatta' corsini Laurentiaux; 6, Sysciophlebia sp. A; 7, Syscioblatta intermedia (Scudder). because of the lack or work on these fossils in recent years. Anthacronauta shells became more elongate in late Westphalian faunas, reflected in the change from A. phillipsi (Williamson) to A. tenuis (Davies and Trueman), which may partly reflect ecological changes (Vasey and Bowes, 1985; Vasey, 1994). However, the tempo of this morphological change has only been studied in a few basins and its significance remains unclear.

\section{Synthesis}

IGCP 469 has revealed that during late Westphalian and early Stephanian times in Euramerica there was a complex interaction between tectonics, climate and vegetation. There was a progressive change from lycopsid-dominated, to mixed fern - lycopsid to ferndominated vegetation. The changes were first seen in eastern Europe, such as the Dobrudzha Coalfield, but progressively spread westwards across Variscan Euramerica (Figure 4). The last significant area of lycopsid-dominated vegetation in Euramerica was in the coalfields of the Interior Province of the USA, where they persisted as a significant component of the wetland vegetation until early Stephanian (late Desmoinesian) times. This change in composition was accompanied by a contraction in the area of the Euramerican swamps, especially in Europe, and by mid-Cantabrian times they were only about half the overall size that they had been in Bolsovian times.

There is, however, little evidence of regional-scale climate change at this time. Where there is evidence for reduced precipitation it is fairly localised; in many areas such as South Wales, the Canadian Maritimes, Central Bohemia and Dobrudzha, peat accumulation (coal) suggesting relatively high precipitation levels continued well into Stephanian times. There is on the other hand evidence of significant tectonic instability across Variscan Euramerica in both foreland and intra-montane settings. This seems to have had little effect on the elevation of the coal basins themselves; the observed withdrawal of marine influence across the area was probably just reflecting the global fall in sea levels resulting from the growth of the Gondwana icecap. Raised elevation on its own would anyway have had little impact on the ability of the coal swamps to thrive, as in mid-Westphalian times swamps were known to have developed at some 1000 $\mathrm{m}$ above sea level, in Central Bohemia (Opluštil, 2005). However, there were clear changes taking place in drainage and sediment influx within the basins, probably triggered by tectonic activity in the hinterlands, and these would potentially have impacted on coal swamp development. The arborescent lycopsids had rooting structures highly adapted to waterlogged substrates (Rothwell, 1984; Phillips and DiMichele, 1992), making them vulnerable to changes in substrate conditions. The marattialean ferns, in contrast, were less constrained to extremely wet conditions (DiMichele and Phillips, 2002) and 
would have been able to replace the lycopsids if the substrates became better drained. It seems unlikely, therefore, that the observed change from lycopsid- to fern-dominated vegetation, and the tectonic disruption to landscapes and drainage patterns were coincidental.

This increase in the contribution of ferns to the coal swamp vegetation was initially likely to have been patchy. However, these ferns had indeterminate growth and so would produce less biomass per unit area than the lycopsids with their determinate growth; they will also have produced a more closed type of canopy than the predominantly pole-like lycopsids. Where the ferns became the dominant plants of the coal swamps the levels of evapo-transpiration would have been substantially reduced. Reduced evapo-transpiration would then have caused a local decline in precipitation, which further accelerated the development of drier substrates and thus the change in vegetation.

It would seem, therefore, that the changes that took place in the coal swamps of Euramerica were more protracted than has been previously envisaged, having taken place over perhaps 3-4 Ma. What is seen in the coalfields of the Interior Province of the USA is merely the culmination of an extended process that gradually rolled-out across Euramerica between Duckmantian and Cantabrian times. There was clearly a feedback cycle between changing vegetation and reduction in precipitation, which further changed the vegetation. However, the overall cycle of change was initiated by landscape instability caused by Variscan tectonics making substrate conditions locally unfavourable for the arborescent lycopsids.

And what about the possible link with the global increases in temperature for which there is evidence in early Stephanian times? There is little direct evidence of increased temperatures in the tropics at this time; the changes in biotas that have been recognised were almost certainly a response to changes in rainfall patterns and substrate moisture than a direct response to temperature change. Increased global temperatures could feasibly have caused the Hadley Cell to weaken resulting in reduced precipitation in the tropical belt (Poulsen et al., 2007; Peyser and Poulsen, 2008); but as we have pointed out, the reduction in precipitation in low latitudes was localised, at least until late Asturian times, when it is also accompanied by wide-scale tectonic disruption to landscapes. On the other hand, the marked change in tropical vegetation and consequential reduction in peat generation may have had an effect on the global carbon cycle. Because of the unusual biology of the arborescent lycopsids (DiMichele and Phillips, 1985, 1994) the contraction of the coal swamps would have been responsible for the loss of an active carbon sink equivalent to an annual increase of atmospheric $\mathrm{CO}_{2}$ of between 0.37 and $0.69 \mathrm{ppm}$ (Cleal and Thomas, 2005; Cleal et al., 2010). It is difficult to be sure how much of the resulting rise in will have been offset by other compensatory sinks such as increased biological productivity in the marine realm or increased erosion of siliciclastics. However, it would seem unlikely that a change in the global carbon cycle on this scale would have had no effect on levels of atmospheric $\mathrm{CO}_{2}$ and that it would have resulted in a rise in global temperatures - exactly what is seen in other parts of the world at about this time.

\section{Acknowledgements}

Thanks go to all of our colleagues in IGCP 469 who brought this project to such a successful conclusion: O.A. Abbink and T. van Hoof (TNO, Utrecht), J. Bek (Institute of Geology, Prague), T. Dimitrova
(Institute of Geology, Sofia), J. Drábková and Z. Šimunek (Czech Geological Survey), Ch. Hartkopf-Fröder and K. Jasper, (Geological Survey, North Rhine-Westphalia), A. Kedzior and M. OliwkiewiczMiklasinska (Institute of Geological Sciences, Kraków), E. Jarzembowski (Maidstone Museum), M. Libertin (National Museum, Prague), D. McLean (MB Stratigraphy, Sheffield), J. Pšenicka (West Bohemian Museum, Plzeò), B. Ptak (Institute of Geological Sciences, Sosnowiec), J.W. Schneider (Technical University and Mining Academy, Freiberg), S. Schultka (Natural History Museum, Berlin), D. Uhl (Senckenberg Institute, Frankfurt), M.I. Waksmundzka (Institute of Geological Sciences, Warsaw), I. van Waveren (Naturalis, Leiden) and E. L. Zodrow (University of Cape Breton, Sydney). The project was supported by UNESCO and IUGS, to whom we are also immensely grateful. Finally, we would like to thank Bill DiMichele (Smithsonian Institution) and another anonymous referee for their constructive review of this paper.

\section{References}

Anderson, J. M., Anderson, H. M., and Cruickshank, A. R. I., 1998, Late Triassic ecosystems of the Molteno/Lower Elliot Biome of southern Africa: Palaeontology, v. 41, pp. 387-421.

Balme, B.E., 1995, Fossil in situ spores and pollen grains: an annotated catalogue: Review of Palaeobotany and Palynology, v. 87, pp. 81-323.

Bek, J., and Opluštil, S., 1998, Some lycopsid, sphenopsid and pteropsid fructifications and their miospores from the Upper Carboniferous basins of the Bohemian Massif: Palaeontographica, Abteilung B, v. 248, pp. $127-161$.

Bek, J., and Opluštil, S., 2004, Palaeoecological constraints of some Lepidostrobus cones and their parent plants from the Late Palaeozoic continental basins of the Czech Republic: Review of Palaeobotany and Palynology, v. 131, pp. 49-89.

Besly, B. M., 1987, Sedimentological evidence for Carboniferous and early Permian palaeoclimates of Europe: Annales de la Société géologique du Nord, v. 106, pp. 131-143.

Besly, B.M., 1988, Palaeogeographic implications of late Westphalian to early Permian red-beds, Central England, in: Besly, B., and Kelling, G., eds, Sedimentation in a synorogenic basin complex, the Upper Carboniferous of northwest Europe: London, Blackie, pp. 200-221.

Besly, B.M., and Cleal, C.J., 1997, Upper Carboniferous stratigraphy of the West Midlands (UK) revised in the light of borehole geophysical logs and detrital compositional suites: Geological Journal, v. 32, pp. 85-118.

Besly, B.M., and Fielding, C.R., 1989, Palaeosols in Westphalian coal-bearing and red-bed sequences, central and northern England: Palaeogeography, Palaeoclimatology, Palaeoecology, v. 70, pp. 303-330.

Besly, B.M., and Turner, P., 1983, Origin of red beds in a moist tropical climate (Etruria Formation, Upper Carboniferous, UK), in Wilson, R.C.L., ed., Residual deposits: Special Publications of the Geological Society, London, v. 11, pp. 131-147.

Butterworth, M.A., 1964, Die Vertleigung der Densosporites sphaerotriangularis im Westfal B der westpenninschen Steinkohlenfelder Englands: Fortschritte in der Geologie von Rheinland und Westfalen, v. 12, pp. 317-330.

Cleal, C.J., 2004, IGCP 469 Late Westphalian terrestrial biotas and environments of the Variscan Foreland and adjacent intramontane basins: Geologica Balcanica, v. 34, pp. 3-10.

Cleal, C.J., 2005, The Westphalian macrofloral record from the cratonic central Pennines Basin, UK: Zeitschrift der Deutschen Gesellschaft für Geowissenschaften, v. 156, pp. 387-410.

Cleal, C.J., 2007, The Westphalian-Stephanian macrofloral record from the South Wales Coalfield: Geological Magazine, v. 144, pp. 465-486.

Cleal, C.J., 2008a, IGCP 469 Late Variscan terrestrial biotas and palaeoenvironments: Studia Geologica Polonica, v. 129, pp. 7-8. 
Cleal, C.J., 2008b, Westphalian-Stephanian macrofloras of the southern Pennines Basin, UK. Studia Geologica Polonica, v. 129, pp. 25-41.

Cleal, C.J., 2008c, Palaeofloristics of Middle Pennsylvanian lyginopteridaleans in Variscan Euramerica: Palaeogeography, Palaeoclimatology, Palaeoecology, v. 261, pp. 1-14.

Cleal, C.J., 2008d, Palaeofloristics of Middle Pennsylvanian medullosaleans in Variscan Euramerica: Palaeogeography, Palaeoclimatology, Palaeoecology, v. 268, pp. 164-180.

Cleal, C.J., Opluštil, S., Thomas, B.A., and Tenchov, Y.G., 2010, Late Moscovian terrestrial biotas and palaeoenvironments of Variscan Euramerica: Netherlands Journal of Geosciences, v. 88 (for 2009), pp. $181-278$.

Cleal, C.J., and Shute, C.H., 2003, Systematics of the Late Carboniferous medullosalean pteridosperm Laveineopteris and its associated Cyclopteris leaves: Palaeontology, v. 46, pp. 353-411.

Cleal, C.J., Tenchov, Y.G., Dimitrova, T.Kh., Thomas, B.A., and Zodrow, E.L., 2007, Late Westphalian-Early Stephanian vegetational changes across the Variscan Foreland, in Wong, Th.E., ed., Proceedings of the $\mathrm{XV}$ th International Congress on Carboniferous and Permian Stratigraphy. Utrecht, the Netherlands, 10-16 August 2003: Amsterdam, Royal Netherlands Academy of Arts and Sciences, pp. 367-377.

Cleal, C.J., and Thomas, B.A., 2005, Palaeozoic tropical rainforests and their effect on global climates: is the past the key to the present?: Geobiology, v. 3, pp. 13-31.

Cridland, A.A., 1968, Alethopteris ambigua Lesquereux, a Pennsylvanian pteridosperm from Missouri, U.S.A.: Botanical Journal of the Linnean Society, v. 61, pp. 107-111.

DiMichele, W.A., and Phillips, T.L., 1985, Arborescent lycopod reproduction and paleoecology in a coal-swamp environment of late Middle Pennsylvanian age (Herrin Coal, Illinois, U.S.A.): Review of Palaeobotany and Palynology, v. 44, pp. 1-26.

DiMichele, W.A., and Phillips, T.L., 1994, Paleobotanical and paleoecological constraints on models of peat formation in the Late Carboniferous of Euramerica: Palaeogeography, Palaeoclimatology, Palaeoecology, v. 106, pp. 39-90.

DiMichele, W.A., and Phillips, T.L., 1996, Climate change, plant extinction and vegetational recovery during Middle-Late Pennsylvanian transition: the case of tropical peat-forming environments in North America, in Hart, M.B., ed., Biotic recovery from mass extinction events: Geological Society, London, Special Publications, v. 102, pp. 201-221.

DiMichele, W.A. and Phillips, T.L., 2002, The ecology of Paleozoic ferns: Review of Palaeobotany and Palynology, v. 119, pp. 143-159.

DiMichele, W.A., Gastaldo, R.A., and Pfefferkorn, H.W., 2005, Plant biodiversity partitioning in the Late Carboniferous and Early Permian and its implications for ecosystem assembly: Proceedings of the California Academy of Sciences, Series 4, v. 56 (Supplement 1), pp. 32-49.

Dimitrova, T.Kh., and Cleal, C.J., 2007, Palynological evidence for late Westphalian-early Stephanian vegetation change in the Dobrudzha Coalfield, NE Bulgaria: Geological Magazine, v. 144, pp. 513-524.

Dimitrova, T.Kh., Cleal, C.J., and Thomas, B.A., 2005, Palynology of late Westphalian early Stephanian coal-bearing deposits in the eastern South Wales Coalfield: Geological Magazine, v. 142, pp. 809-821.

Dimitrova, T.Kh., Zodrow, E.L., Cleal, C.J., and Thomas, B.A., 2010, Palynological evidence for Pennsylvanian (Late Carboniferous) vegetation change in the Sydney Coalfield, eastern Canada: Geological Journal, v. 45, pp. 388-396.

Doktor, M., and Gradzinski, R., 2000, Sedimentary environments and depositional systems of coal bearing succession of the Upper Silesian Coal Basin: Proceedings of XXIII Symposium Geology of Coal-Bearing Strata of Poland, pp. 29-33. [In Polish, with English summary].

Dreesen, R., Bossiroy, D., Dusar, M., Flores, R.M., and Verkaeren, P., 1995, Overview of the influence of syn-sedimentary tectonics and palaeo-fluvial systems on coal seam and sand body characteristics in the Westphalian C strata, Campine Basin, Belgium, in Whateley, M.K.G., and Spears, D.A., eds, European coal geology: Geological Society, London, Special Publication, v. 82, pp. 215-232.
Dunlop, J.A., 1994, The palaeobiology of the Writhlington trigonotarbid arachnid: Proceedings of the Geologists' Association, v. 105, pp. 287 296.

Durante, M.V., 1995, Reconstruction of Late Paleozoic climatic changes in Angaraland according to phytogeographic data: Stratigraphy and Geological Correlations, v. 3, pp. 123-133.

Fielding, C.R., Frank, T.D., Birgenheier, L.P., Rygel, M.C., Jones, A.T., and Roberts, J., 2008, Stratigraphic imprint of the Late Palaeozoic Ice Age in eastern Australia: a record of alternating glacial and nonglacial climate regime: Journal of the Geological Society, London, v. 165, pp. 129-140.

Gaitzsch, B., Rößler, R., Schneider, J. W., and Schretzenmayer, S., 1998 , Neue Ergebnisse zur Verbreitung potentieller Muttergesteine im Karbon der variscischen Vorsenke in Nordostdeutschland: Geologisches Jahrbuch, v. A 149 , pp. $25-58$.

Galtier, J., 1997, Coal-ball floras of the Namurian-Westphalian of Europe: Review of Palaeobotany and Palynology, v. 95, pp. 51-72.

Gayer, R.A., Cole, J.E., Greiling, R.O., Hecht, C., and Jones, J.A., 1993, Comparative evolution of coal-bearing foreland basins along the Variscan northern margin in Europe, in Gayer, R.A., Greiling, R.O., and Vogel, A.K., eds, Rhenohercynian and Subvariscan fold belts: Braunschweig, Vieweg and Sons, pp. 47-82.

Gayer, R.A., and Jones, J.A., 1989, The Variscan Foreland in South Wales: Proceedings of the Ussher Society, v. 7, pp. 177-179.

González, C.R., 1990, Development of the Late Paleozoic glaciations of the South American Gondwana in western Argentina: Palaeogeography, Palaeoclimatology, Palaeoecology, v. 79, pp. 275-287.

Guion, P.D., and Fielding, C.R., 1988, Westphalian A and B sedimentation in the Pennines Basin, UK, in Besly, B., \& Kelling, G., eds Sedimentation in a synorogenic basin complex, the Upper Carboniferous of northwest Europe: London, Blackie, pp. 153-177.

Guion, P.D., Fulton, I.M., and Jones, N.S., 1995, Sedimentary facies of the coal-bearing Westphalian A and B north of the Wales-Brabant High: Special Publication of the Geological Society of London, v. 82, pp. 4578.

Hartley, A.J., 1993, Silesian sedimentation in south-west Britain: sedimentary responses to the developing Variscan Orogeny, in Gayer, R.A., Greiling, R.O., and Vogel, A.K., eds, Rhenohercynian and Subvariscan fold belts: Braunschweig, Vieweg and Sons, pp. 157-196.

Jachowicz, A., 1972, Charakterystyka mikroflorystyczna i stratygrafia karbonu produktywnego Górnoœ1 ${ }^{1}$ skiego Zag3êbia Wêglowego: Prace Instytutu Geologicznego, v. 61, pp. 185-277.

Jachowicz, A., and Dybova-Jachowicz, S., 1983, Application of palynology to geological research in Carboniferous coal basins of Poland, in Bojkowski, K., and Porzycki, J., eds, Geological problems of coal basins of Poland: Warsaw, Geological Institute, pp. 165-185.

Jarzembowski, E.A., 2007, IGCP 469 - Late Variscan terrestrial biotas and palaeoenvironments: African Invertebrates, v. 48, p. 248

Jarzembowski, E.A., and Schneider, J.W., 2007, The stratigraphical potential of blattodean insects from the late Carboniferous of southern Britain: Geological Magazine, v. 144, pp. 449-456.

Jasper, K., Hartkopf-Fröder, C., Flajs, G., and Littke, R., 2010, Evolution of Pennsylvanian (Late Carboniferous) peat swamps of the Ruhr Basin, Germany: Comparison of palynological, coal petrographical and organic geochemical data: International Journal of Coal Geology, v. 83, 4, pp. 346-365.

Kedzior, A., Gradziñski, R., Doktor, M., and Gmur, D., 2007, Sedimentary history of a Mississippian to Pennsylvanian coal-bearing succession an example from the Upper Silesia Coal Basin, Poland: Geological Magazine, v. 144, pp. 487-496.

Lojka, R., Drábková, J., Zajíc, J., Sýkorová, I., Francu, J., Bláhová, A., and Grygar, T., 2009, Climate variability in the Stephanian B based on environmental record of the Mšec Lake deposits (Kladno-Rakovník Basin, Czech Republic): Palaeogeography, Palaeoclimatology, Palaeoecology, v. 280, pp. 78-93.

Marshall, A.E., and Smith, A.H.V., 1964, Assemblages of miospores from some Upper Carboniferous coals and their associated sediments in the 
Yorkshire Coalfield: Palaeontology, v. 7, pp. 656-673.

Marshall, J.E.A., 2005, Arthur Raistrick: Britain's premier palynologist, in Bowden, A.J., Burek, C.V., and Wilding, R., eds, History of palaeobotany: Geological Society, London, Special Publication, v. 241, pp. 161-179.

Meyen, S.V., 1982, The Carboniferous and Permian floras of Angaraland (a synthesis): Biological Memoirs, v. 7, pp. 1-110.

Moore, L.R. \& Blundell, C.R.K., 1952, Some effects of the Malvernian phase of earth movements in the South Wales Coalfield, a comparison with other coalfields in south Britain: Compte rendu, $3 \mathrm{e}$ Congrès International de Stratigraphie et de Géologie du Carbonifère (Heerlen), v. 2, pp. 463473.

Nelson, J.W., 1987, Coal deposits of the United States: International Journal of Coal Geology, v. 8, pp. 355-365.

Opluštil, S., 2004, Late Carboniferous tectono-sedimentary evolution and related terrestrial biotic changes on the Northern Variscan and Appalachian forelands, and adjacent paralic and continental basins: Geologica Balcanica, v. 34, pp. 51-69.

Opluštil, S., 2005, Evolution of the Middle Westphalian river valley drainage system in central Bohemia (Czech Republic) and its palaeogeographic implication: Palaeogeography, Palaeoclimatology, Palaeoecology, v. 222, pp. 223-258.

Opluštil, S., and Cleal, C.J., 2007, A comparative analysis of some Late Carboniferous basins of Variscan Europe: Geological Magazine, v. 144, pp. $417-448$

Opluštil, S., Sýkorová, I., and Bek, J., 1999, Sedimentology, coal petrography and palynology of the Radnice Member in the S-E part of the KladnoRakovník Basin, Central Bohemia: Acta Universitatis Carolinae Geologica, v. 43, pp. 599-623.

Peppers, R.A., 1996, Palynological correlation of major Pennsylvanian (Middle and Upper Carboniferous) chronostratigraphic boundaries in the Illinois and other coal basins: Geological Society of America Memoir, v. 188 , pp. $1-111$.

Pešek, J., 1994, Carboniferous of Central and Western Bohemia (Czech Republic): Czech Geological Survey, Prague.

Pešek, J., 2004, Late Palaeozoic limnic basis and coal deposits of the Czech Republic: Folia Musei Rerum Naturalium Bohemiae Occidentalis, Geologica, v. 1, pp. 1-188.

Peyser, C.E., and Poulsen, C.J., 2008, Controls on Permo-Carboniferous precipitation over tropical Pangaea: a GCM sensitivity study: Palaeogeography, Palaeoclimatology, Palaeoecology, v. 268, pp. 181192.

Phillips, T.L., and DiMichele, W.A., 1992, Comparative ecology and lifehistory biology of arborescent lycopsids in Late Carboniferous swamps of North America: Annals of the Missouri Botanical Garden, v. 79, pp. $560-588$.

Phillips, T.L., and Peppers, R.A., 1984, Changing patterns of Pennsylvanian coal-swamp vegetation and implications of climatic control on coal occurrence: International Journal of Coal Geology, v. 3, pp. 205-255.

Phillips, T.L., Peppers, R.A., and DiMichele, W.A., 1985, Stratigraphic and interregional changes in Pennsylvanian coal-swamp vegetation: environmental inferences: International Journal of Coal Geology, v. 5, pp. 43-109.

Poulsen, C.J., Pollard, D., Montañez, I., and Rowley, D., 2007, Late Paleozoic tropical climate response to Gondwanan glaciations: Geology, v. 35, pp. 771-774.

Rothwell, G.W., 1984, The apex of Stigmaria (Lycopsida) ; rooting organ of Lepidodendrales: American Journal of Botany, v. 71, pp. 1031-1034.

Schneider, J.W., Hoth, K., Gaitzsch, B.G., Berger, H.J., Steinborn, H., Walter, H., and Zeidler, M.K., 2005, Carboniferous stratigraphy and development of the Erzgebirge Basin, East Germany: Zeitschrift der Deutschen Gesellschaft für Geowissenschaften, v. 156, pp. 431-466.

Shi, G.R., and Waterhouse, J.B., 2010, Late Palaeozoic global changes affecting high-latitude environments and biotas: Palaeogeography, Palaeoclimatology. Palaeoecology, v. 298, pp. 1-16.

Shulga, W.F., Zdanowski, A., Zaytseva, L.B., Ivanova, A.W., Korol, N.D., Kotasowa, A., Kotas, A., Kostik, I.E., Lelik, B.I., Migier, T., Manitshev, W.I., Matrofailo, M.N., Ptak, B., Savtchuk, W.S., Sedaeva, G.M., and Stepanenko, J.G., 2007, Correlation of the Carboniferous coal-bearing formations of the Lviv-Volyn and Lublin basins. [in Russian, English summary]: National Academy of Sciences of Ukraine, Kiev and Institute of Geological Sciences (Upper Silesian Branch), Sosnowiec.

Šimunek, Z., 2004, The Upper Westphalian flora of the Bohemian Massif (pteridosperms, cordaites and extrabasinal elements): Geologica Balcanica, v. 34, pp. 77-84.

Šimunek, Z., 2007, New classification of the genus Cordaites from the Carboniferous and Permian of the Bohemian Massif, based on cuticle micromorphology: Sborník Národního Muzea v Praze, Serie B, Pøírodní Vìdy, v. 62, pp. 97-210.

Smith, A.H.V., 1957, The sequence of microspore assemblages associated with the occurrence of crassidurite in coals seams of Yorkshire: Geological Magazine, v. 94, pp. 345-363.

Smith, A.H.V., 1962, The palaeoecology of Carboniferous peats based on the miospores and petrography of bituminous coals: Proceedings of the Yorkshire Geological Society, v. 33, pp. 423-474.

Snigirevskya, N.S., 1972, Studies of coal balls of the Donets: Review of Palaeobotany and Palynology, v. 14, pp. 197-204.

Tenchov, Y., 1993, Sedimentation and erosion during the Late Carboniferous in the Dobrudzha coal field (northeast Bulgaria): Geologica Balcanica, v. 23, pp. 3-18.

Tenchov, Y.G., 2005, Early Westphalian sediments of Dobrudzha Coalfield (NE Bulgaria) - an interpretation of their stratigraphy and sedimentation conditions: Zeitschrift der Deutschen Gesellschaft für Geowissenschaften, v. 156 , pp. $467-480$

Tenchov, Y.G., 2007, Late Westphalian and early Stephanian sediments of the Dobrudzha Coalfield, NE Bulgaria: Geological Magazine, v. 144, pp. 497-511.

Thomas, B.A., 2007, Phytogeography of Asturian (Westphalian D) lycophytes throughout the Euramerican belt of coalfields: Geological Magazine, v. 144, pp. 457-463.

Thomas, B.A., and Tenchov, Y., 2004, The Upper Westphalian lycophyte floras of the Dobrudzha Coalfield (Bulgaria) and a comparison with those of southern Britain and Cape Breton (Canada): Geologica Balcanica, v. 34 , pp. $105-110$.

Uhl, D., and Cleal, C.J., 2010, Late Carboniferous vegetation change in lowland and intramontane basins in Germany: International Journal of Coal Geology. v. 83, pp 318-328.

Vasey, G.M., 1994, Classification of Carboniferous non-marine bivalves: systematics versus stratigraphy: Journal of the Geological Society, v. 151, pp. 1023-1033.

Vasey, G.M., and Bowes, G.E., 1985, The use of cluster analysis in the study of some non-marine bivalvia from the Westphalian D of the Sydney Coalfield, Nova Scotia, Canada: Journal of the Geological Society, v. 142, pp. 397-410.

Wagner, R. H., 1966, Palaeobotanical dating of Upper Carboniferous folding phases in NW. Spain: Memorias del Instituto Geologico y Minero de España, v. 66, pp. 1-169.

Wagner, R.H., and Winkler Prins, C.F., 1970, The stratigraphic succession, flora and fauna of Cantabrian and Stephanian A rocks at Barruelo (prov. Palencia), N.W. Spain, in Streel, M., and Wagner, R.H., eds, Colloque sur la stratigraphie du Carbonifère: Les Congrès et Colloque de l’Université de Liège, v. 55, pp. 487-551.

Wilkinson, H.P., 1979, The plant surface (mainly leaf), in Metclafe, C.R., and Chalk, L., eds, Anatomy of the dicotyledons ( $2^{\text {nd }}$ edition). Volume I: Clarendon Press, Oxford, pp. 97-165. 


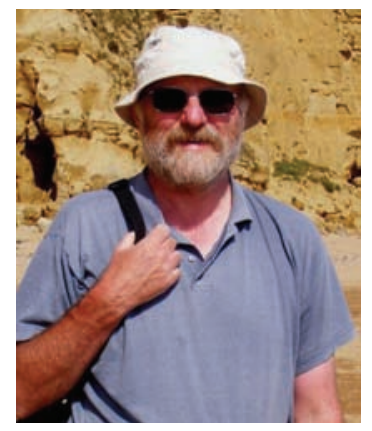

Chris Cleal was senior coordinator of IGCP 469, as well as of the newlyestablished IGCP 575. He is Head of the Vegetation History Section of Amgueddfa Cymru (Cardiff) and specialises in Carboniferous floras, especially pteridosperms, marattialean ferns and sphenophytes. He helped develop the use of cuticles for improving pteridosperm taxonomy, and has used various multivariate statistical analyses to establish palaeobiogeographical and biostratigraphical distribution patterns of the species.

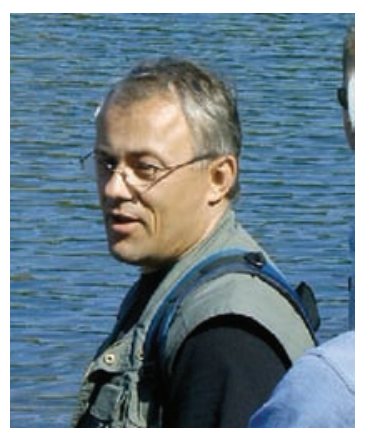

Stanislav Opluštil is an associate professor and Vice-Head of the Institute of Geology and Palaeontology, Faculty of Science, Charles University in Prague, Czech Republic. He specialises in the genesis of coal-bearing strata, basin stratigraphy and palaeogeography, coal petrography, palaeobotany and palaeoecology of the Late Palaeozoic terrestrial ecosystems. He has participated in many domestic and several international grant projects including the IGCP 469 and IGCP 575.

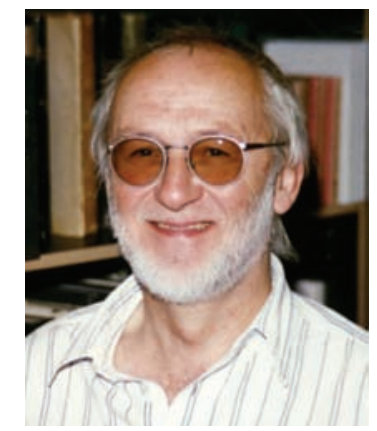

Barry A Thomas was one of the coordinators of IGCP 469. He has studied the taxonomy, geographical and stratigraphical distribution of Carboniferous herbaceous and arborescent lycophytes for over 40 years. His involvement in IGCP extended the knowledge of lycophyte distribution throughout thirteen coalfields in Europe and the Canadian Maritimes during the late Moscovian times. He is Treasurer of the British Institute for Geological Conservation.

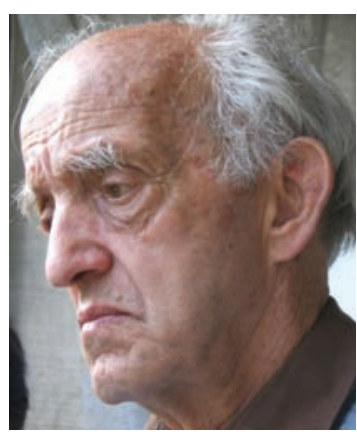

Yanaki Tenchov was one of the coordinators of IGCP 469. He was a geologist with the Geological Institute, Bulgarian Academy of Sciences (Sofia) and has worked extensively on the Palaeozoic macrofloras and terrestrial deposits of Bulgaria. He has been particularly interested in the palaeoclimatic signal revealed by the floras, revealed by a comparison between the upland Svoge coal basin and the lowland Dobrudzha coal basin. He was a member of the IUGS International Subcommission on Stratigraphic Classification responsible for the development of the 1976 International Stratigraphic Guide. 